UDK 366.542:35.087.44

https://doi.org/10.18485/union_pf_ccr.2021.ch23

\author{
Prof. dr Katarina Ivančević
}

\title{
ZAŠTITA POTROŠAČA KORISNIKA USLUGE OSIGURANJA OD NEPRAVIČNIH UGOVORNIH ODREDABA**
}

\begin{abstract}
Apstrakt: U ovom radu ćemo razmotriti na koji način se štite interesi korisnika usluge osiguranja koji imaju svojstvo potrošača u srpskom $i$ uporednom pravu kroz odredbe zakona kojima se uređuje ugovor o osiguranju. U radu su razmatrana zakonodavna rešenja srpskog prava sa osvrtom na rešenja iz uporednog prava, odredbe PEICL-a, kao i promene koje se predlažu u srpskom pravu u Prednacrtu Građanskog zakonika Republike Srbije. Analiza je pokazala da postoji potreba da se važeće odredbe kojima se uređuje ugovor o osiguranju u srpskom pravu osavremene uvođenjem posebnih pravila kojima se obezbeđuje zaštita korisnika usluge osiguranja, posebno potrošača, od nepravičnih ugovornih odredaba. Kao dobar uzor mogu poslužiti neka uporednopravna rešenja koja su prikazana u ovom radu. Rešenja iz Prednacrta GZ-a Srbije su dobrim delom u skladu sa savremenim rešenjima iz uporednog prava i odredbama PEICL-a. Autorka daje svoje sugestije i predloge za izmenu predloženih rešenja.
\end{abstract}

Ključne reči: korisnik usluge osiguranja, nepravične ugovorne odredbe, zaštita potrošača.

\section{UVOD}

Sa ciljem da se zaštite potrošači od nepravičnih ugovornih odredaba u standardnim uslovima, u EU je doneta Direktiva 93/13/EEZ o nepravičnim klauzulama u potrošačkim ugovorima ${ }^{1}$ čije odredbe su u srpskom pravu primenjene $u$ odredbama Zakona o zaštiti potrošača $(\mathrm{ZZP}) .^{2}$ Istraživanje koje je sprovedeno u EU pokazalo je da je $45 \%$ evropskih potrošača profitiralo od tumačenja nejasnih ugovornih odredaba u korist potrošača kao slabije ugovorne strane, što je omogućeno primenom Direktive 93/13. ${ }^{3}$ Evropska komisija je donela Smernice za

* Redovna profesorka Pravnog fakulteta Univerziteta Union, e-mail: katarina.ivancevic@pravnifakultet.rs

** Rad je napisan kao rezultat istraživanja na naučnom projektu Pravnog fakulteta Univerziteta Union u Beogradu - Zaštita kolektivnih interesa potrošača u srpskom i uporednom pravu.

1 Council Directive 93/13/EEC of 5 April 1993 on unfair terms in consumer contracts, Official Journal L95, 21. 4. 1993, pp. 29-34 (u daljem tekstu: Direktiva 93/13).

2 Zakon o zaštiti potrošača, Sl. glasnik RS, br. 62/14 i 6/16 (dr. zakon), (u daljem tekstu: ZZP).

$3 \quad$ Fitness Check of Consmuer and Marketing Law, Brussels, 23. 5. 2017. SWD (2017) 208 final. 
tumačenje i primenu Direktive 93/13. ${ }^{4}$ Osnovni cilj ovih smernica je da se prikažu tumačenja Evropskog suda o ključnim pojmovima i odredbama Direktive u svetlu konkretnih slučajeva koje su rešavali nacionalni sudovi.

U srpskom pravu se na odnose povodom ugovora o osiguranju primenjuju prvenstveno odredbe Zakona o obligacionim odnosima (ZOO). ${ }^{5}$ Zakon koji uređuje obavljanje delatnosti osiguranja ${ }^{6}$ upućuje da se na ugovor o osiguranju primenjuje zakon kojim se uređuju obligacioni odnosi, s tim da se primenjuju i odredbe drugih zakona koje se odnose na ugovore o pojedinim vrstama osiguranja, osim ako pojedina pitanja nisu drugačije uređena ovim zakonom. Zakon kojim se uređuju obavezna osiguranja u saobraćaju na isti način kao i ZO upućuje na primenu ZOO i drugih odgovarajućih zakona na ugovore o obaveznom osiguranju. ${ }^{7}$ Zakon koji uređuje zaštitu korisnika finansijskih usluga pri zaključenju ugovora na daljinu upućuje na primenu odredaba zakona kojim se uređuju obligacioni odnosi. ${ }^{8} \mathrm{U}$ organizaciji i sprovođenju dobrovoljnog zdravstvenog osiguranja takođe se primenjuju odredbe zakona kojim se uređuju obligacioni odnosi. ${ }^{9}$ Odredbe ZZP-a upućuju da se na odnose između potrošača i trgovca, koji nisu uređeni odredbama ovog zakona, primenjuje zakon kojim se uređuju obligacioni odnosi. ${ }^{10}$

U uporednom pravu u pojedinim zakonima koji uređuju ugovorno pravo osiguranja propisano je da se na ugovore o osiguranju primenjuju odredbe zakona kojim se štite prava potrošača, ukoliko nije drugačije nešto propisano tim zakonom za pojedini slučaj. ${ }^{11} \mathrm{U}$ francuskom pravu pojedine odredbe zakona upućuju na primenu određenih odredaba zakona kojima se štite prava potrošača kada se zaključuje ugovor o osiguranju. ${ }^{12} \mathrm{U}$ srpskom pravu na shodnu primenu odredaba ZZP-a na pitanja zaštite korisnika usluge osiguranja upućuju jedino odredbe ZZKFUD-a. ${ }^{13}$ Ostali zakoni koji su značajni za delatnost osiguranja,

4 Commission notice - Guidance on the interpretation and application of Council Directive 93/13/EEC on unfair terms in consumer contracts (Text with EEA relevance.), OJ C 323, 27. 9. 2019, pp. 4-92 (u daljem tekstu: Commission notice).

5 Zakon o obligacionim odnosima, Sl. list SFRJ, br. 2978, 39/1985, 45 i 57/1989, Sl. list SRJ, br. 31/93, Sl. list SCG, br. 1/03 - Ustavna povelja (u daljem tekstu: ZOO).

6 Član 18. stav 2. Zakona o osiguranju, Sl. glasnik RS, br. 139/14 (u daljem tekstu: ZO).

7 Član 13. Zakona o obaveznom osiguranju u saobraćaju, Sl. glasnik RS, br. 51/09, 78/11, 101/11, 93/12, 7/13 - odluka US, (u daljem tekstu: ZOOS).

8 Član 3. stav 1. Zakona o zaštiti korisnika finansijskih usluga kod ugovora na daljinu, Sl. glasnik RS, br. 44/18 (u daljem tekstu: ZZKFUD).

9 Član 3. stav 3. Uredbe o dobrovoljnom zdravstvenom osiguranju, Sl. glasnik RS, br. 108/08, 49/09, (u daljem tekstu: Uredba DZO).

10 Član 3. stav 7. ZZP. Na sličan način i u hrvatskom pravu - član 4. stav 2. Zakona o zaštiti potrošača, Narodne novine, br. 41/14, 110/15, 14/19 (u daljem tekstu: ZZP Hrvatske).

11 Član 3. stav 1. Loi du 27 juillet 1997 sur le contrat d'assurance - Zakon o ugovoru o osiguranju Luksemburga, (u daljem tekstu: ZUO Luksemburga). Primenjuju se odredbe Zakona od 8. aprila 2011. o proglašenju Zakona o potrošačima.

12 U francuskom pravu je predviđeno da se na pružanje usluge osiguranja na daljinu potrošačima primenjuju određene odredbe Zakona o potrošačima - član 112-2-1, stav 1. French Insurance Code - Francuski zakonik o osiguranju, (u daljem tekstu: Francuski ZO). 
kao što su ZO i ZOOS, kao i ZOO ne upućuju na primenu ZZP-a na potrošačke ugovore o osiguranju. S obzirom na to da se odredbe Direktive 93/13 primenjuju i na finansijske usluge, ${ }^{14}$ što podrazumeva i ugovor o osiguranju, u teoriji i praksi je prihvaćeno da se odredbe ZZP-a koje se odnose na nepravične ugovorne odredbe primenjuju i na ugovor o osiguranju kada je korisnik usluge potrošač. Kako bi se otklonile eventualne nedoumice oko primene odredaba ZZP-a, čini nam se dobro rešenje da se zakonom koji uređuje delatnost osiguranja izričito predvidi primena njegovih odredaba, što je primenjeno u pojedinim zakonima u regionu. ${ }^{15}$

Na nivou Evropske unije nije postignuta saglasnost o ujednačavanju pravila $\mathrm{u}$ pogledu ugovornog prava osiguranja. ${ }^{16}$ Kao model opcionog instrumenta komunitarnog prava, koji bi mogao da pomogne u otklanjanju uočenih problema za prekograničnu prodaju osiguranja, pripremljena su Načela evropskog ugovornog prava osiguranja (PEICL). ${ }^{17}$ Odredbe PEICL-a su poslužile kao uzor za neka nova rešenja u Prednacrtu Građanskog zakonika Republike Srbije, ${ }^{18}$ kao i propisi komunitarnog prava kojima se uređuje zaštita potrošača. ${ }^{19}$

\section{POJAM (POTROŠAČA) KORISNIKA USLUGE OSIGURANJA}

Kroz odredbe ugovornog zakonodavstva se obezbeđuje zaštita slabije ugovorne strane koja zaključuje ili izvlači benefite iz ugovora o osiguranju, pod kojom se podrazumevaju ugovarač osiguranja, osiguranik i korisnik osiguranja. Zakonsko regulisanje ugovora o osiguranju je odigralo veliku ulogu u zaštiti korisnika usluge osiguranja tako da se s vremenom ugovor o osiguranju afirmisao kao ugovor po pristanku u užem smislu. ${ }^{20}$ Svojevremeno se nije prepoznavala potreba da se potrošačima pruža dodatna zaštita u vezi sa ugovorom o osiguranju. U tom smislu je i odredbama ZOO obezbeđena zaštita interesa osiguranika i

14 Evropski sud je u svojim odlukama ukazao da se Direktiva 93/13 primenjuje u svim sektorima. Predmet C-290/16 Air Berlin, t. 44, Commission notice, p. 12.

15 Na primer: „Na pitanja iz oblasti zaštite korisnika osiguranja i rad ombudsmana, koja nisu uređena ovim zakonom, primenjuju se propisi koji uređuju oblast zaštite potrošača, postupak medijacije i obligacione odnose." - član 212, stav 2. Zakona o osiguranju, Sl. novine Federacije $\mathrm{BiH}$, br. 23/17, (u daljem tekstu: ZO Federacije BiH).

16 Komisija je 1979/1980. izradila nacrt direktive koja je predviđala osnovnu harmonizaciju prava o ugovoru o osiguranju. Ovaj predlog je naišao na otpor određenih krugova, nije dalje razrađivan i 1993. godine je zvanično povučen. Materijalno-pravna harmonizacija je izvršena pojedinačno na polju obaveznog osiguranja motornih vozila i osiguranja pravne zaštite.

17 Restatement of European Insurance Contract Law, Principles of European Insurance Contract Law, (PEICL), November 1, 2015, (u daljem tekstu: PEICL), (www.restatement.info).

18 Prednacrt Građanskog zakonika Republike Srbije, (u daljem tekstu: Prednacrt GZ-a Srbije), 2016, Pravni život, 5-6, str. 139-544.

19 Šulejić, P., 2010, Predlog tema za javnu raspravu o novim rešenjima koja sadrži Prednacrt Građanskog zakonika RS u odnosu na ugovore o osiguranju, Pravni život, 11, str. 602.

20 Blagojević, B., 1934, Ugovori po pristupu (formularni ugovori), doktorska disertacija, Beograd, str. 139. 
korisnika osiguranja. S vremenom, pod uticajem potrošačkih direktiva, dolazi do promena u uporednom pravu. Pojedini noviji zakoni koji uređuju ugovor o osiguranju predviđaju posebna pravila za situacije u kojima se zaključuje potrošački ugovor o osiguranju, odnosno kada ugovarač osiguranja ima status potrošača. ${ }^{21}$ Kreatori PEICL-a su imali u vidu odredbe potrošačkih direktiva, ali su se opredelili da se kroz odredbe PEICL-a štite interesi slabije ugovorne strane - ugovarača osiguranja, osiguranika i oštećenih lica (dalje: korisnika usluge osiguranja), a ne samo potrošača. Prihvatili su stavove teorije koja smatra da ne treba ograničiti zaštitu, između ostalog i od nepravičnih ugovornih odredaba, samo na potrošače već je treba garantovati svim osiguranicima koji kao pojedinci zaključuju ugovore o masovnim rizicima. ${ }^{22}$

Odredbama ZO se, između ostalog, uređuje zaštita prava osiguranika, ugovarača osiguranja, korisnika osiguranja i trećih oštećenih lica, koji se nazivaju korisnicima usluge osiguranja. ${ }^{23}$ Pojam „korisnik“, koji je definisan Smernicama koje je donela Narodna banka Srbije, podrazumeva fizičko ili pravno lice koje je osiguranik, ugovarač osiguranja, korisnik osiguranja i treće oštećeno lice, a koje koristi ili je koristilo usluge osiguranja ili se osiguravaču, odnosno intermedijaru obratilo radi korišćenja tih usluga. ${ }^{24} \mathrm{Na}$ ovaj način se u srpskom pravu propisima kojima se uređuje delatnost osiguranja obezbeđuje zaštita širokom krugu lica, kako fizičkim tako i pravnim licima koja su korisnici usluge osiguranja.

Kod ugovora o osiguranju na daljinu je u srpskom pravu sužen pojam korisnika na fizičko lice koje uslugu osiguranja koristi u svrhe koje nisu namenjene njegovoj poslovnoj ili drugoj komercijalnoj delatnosti, kao i licima koja imaju svojstvo preduzetnika i poljoprivrednika. ${ }^{25}$ Ovim je pojam potrošača u srpskom pravu proširen u odnosu na definiciju iz evropske direktive. Naime, prema odredbama Direktive 2002/65/EZ potrošač je definisan kao fizičko lice koje u ugovorima na daljinu deluje sa ciljem koji je van njegove trgovačke delatnosti, poslovanja, odnosno struke. ${ }^{26} \mathrm{Na}$ ovu definiciju se oslanjaju i druge direktive iz

21 Tako na primer: Civil code Hungary - Građanski zakonik Mađarske, (u daljem tekstu: GZ Mađarske), čl. 6:444, 6:455, 6:456. Republic of Bulgaria, Insurance code - Bugarski Zakonik o osiguranju, 2005, (u daljem tekstu: Bugarski ZO), sadrži posebne odredbe o potrošačkim informacijama koje se moraju pružiti pre zaključenja ugovora, član 185.

22 Masovni rizici podrazumevaju one rizike koji proizilaze iz ugovora koji su zaključeni sa fizičkim licima - potrošačima ili ugovori koji nemaju veliku vrednost. Keglević, A., 2013, Zaštita osiguranika pojedinca kod ugovora o osiguranju, Zbornik Pravnog fakulteta Sveučilišta u Rijeci, Vol. 34, br. 1, str. 214.

23 Čl. 1. i 15. ZO.

24 „Intermedijar je licencirano društvo za posredovanje u osiguranju, društvo za zastupanje u osiguranju, fizičko lice preduzetnik - zastupnik u osiguranju, kao i banka, davalac finansijskog lizinga i javni poštanski operator koji obavljaju poslove zastupanja u osiguranju”, Narodna banka Srbije, Smernice o minimalnim standardima ponašanja i dobroj poslovnoj praksi učesnika na tržištu osiguranja, od 2. aprila 2018, G. br. 3092, str. 3 (u daljem tekstu: Smernice, 2018).

25 Član 2. stav 1. tačka 5. ZZKFUD.

26 Član 2. stav 1. tačka (d) Directive 2002/65/EC of the European Parliament and of the Council of 23 September 2002 concerning the distance marketing of consumer financial services and amending Council Directive 90/619/EEC and Directives 97/7/EC and 98/27/EC, OJ L 271, 9. 10. 2002, pp. 16-24. 
oblasti osiguranja koje imaju za cilj obezbeđenje zaštite potrošača u osiguranju kada u tekstovima navode pojam „potrošač ", ali ga ne definišu. ${ }^{27}$

U srpskom pravu nije, ni u propisima ni u sudskoj praksi, definisano ko se smatra potrošačem korisnikom usluge osiguranja. Shodnom primenom odredaba ZZP-a ${ }^{28}$ potrošačem korisnikom usluge osiguranja (dalje u tekstu: potrošač) može se smatrati korisnik usluge osiguranja koji je fizičko lice. Uslov je da ovo lice pribavlja, odnosno koristi ili izvlači benefite iz ugovora o osiguranju u svrhe koje nisu namenjene njegovoj poslovnoj ili drugoj komercijalnoj delatnosti. Navedeno podrazumeva da je potrošač kako ugovarač osiguranja, tako i osiguranik i korisnik osiguranja iz ugovora o osiguranja imovine, lica, života i ugovora o osiguranju od građanske odgovornosti. ${ }^{29}$

U Prednacrtu GZ-a Srbije se ne pominju izričito potrošači. Međutim, predviđaju se neka posebna pravila kada je ugovarač osiguranja fizičko lice koje deluje van okvira njegove komercijalne ili profesionalne delatnosti. ${ }^{30}$ Sličan pristup je primenjen i u uporednom pravu. U portugalskom pravu se samo fizičkim licima omogućava da odustanu od ugovora o osiguranju bez navođenja razloga i određuju se posebna pravila koja se ne primenjuju u osiguranju velikih rizika. ${ }^{31} \mathrm{U}$ belgijskom pravu su predviđena posebna pravila u pogledu obima informacija koje se moraju dostaviti ugovaraču osiguranja kada je to fizičko lice. ${ }^{32}$

U evropskom pravu se, kroz direktive koje su uređivale određena pitanja vezana za obavljanje delatnosti životnog i neživotnog osiguranja, oblikovao pojam „potrošač osiguranik“ kao „fizičkog lica koje zbog svojih ličnih karakteristika, veličine i rizika koje osigurava zahteva posebnu zaštitu države“. ${ }^{33}$ Ova posebna zaštita države je potrebna zbog toga što se usluga osiguranja smatra složenom finansijskom uslugom i potrošač po pravilu nije svestan rizičnosti određenog proizvoda osiguranja, posebno kada se njegov učinak pokazuje tek

27 Directive 2009/138/EC of the European Parliament and of the Council of 25 November 2009 on the taking up and pursuit of the business of Insurance and Reinsurance (Solvency II), OJ L 335, 17/12/2009, pp. 0001-0155, (u daljem tekstu: Direktiva 2009/138), kao i Directive (EU) 2016/97 of the European Parliament and of the Council of 20 January 2016 on insurance distribution, OJ L 26. 2. 2016, pp. 19-59 (u daljem tekstu: Direktiva 2016/97).

28 Član 5. stav 1. tačka 1. ZZP. Na nivou EU je usaglašena jedinstvena definicija pojma potrošača koja je primenjena u propisima država članica, kao i u srpskom pravu u odredbama ZZP-a, član 5. stav 1. tačka 1. Directive 2011/83/EU of the European Parliament and of the Council of 25 October 2011 on consumer rights, 22. 11. 2011, OJ L 304/64, (u daljem tekstu: Direktiva 2011/83/EU), član 2. stav 1. tačka 1.

29 Navedeno rešenje je prihvaćeno i u uporednom pravu. Ivančević, K., Usklađenost regulative Republike Srbije sa evropskim pravom u domenu zaštite potrošača usluge osiguranja, u: Slavnić, J., Pak, J., (ur.), 2011, Promene u pravu osiguranja Srbije u okviru evropskog (EU) razvoja prava osiguranja, Udruženje za pravo osiguranja Srbije, str. 239.

30 Član 1414. stav 1. član 1440. stav 3. Prednacrta GZ-a Srbije.

31 Član 118, čl. 12. i 13. Decreto-Lei n. ${ }^{\circ} 72 / 2008$, Diário da República, $1 .{ }^{a}$ série $-N .^{\circ} 75-16$ de Abril de 2008, with the amendments implemented by Law no. $147 / 2015$. - Zakon Republike Portugalije, (u daljem tekstu: ZR Portugalije).

32 Član 32. The Law of 4 April 2014 "on insurance" - Zakon o osiguranju Kraljevine Belgije, 2014, (u daljem tekstu: ZO Belgije).

33 Keglević, A., 2016. Ugovorno pravo osiguranja, Školska knjiga, Zagreb, str. 17. 
u budućnosti. ${ }^{34}$ Fizička lica, posebno ona koja imaju svojstvo potrošača, nemaju dovoljno znanja koje bi im omogućilo da donesu racionalnu, ekonomski najpovoljniju odluku pri nabavci usluge osiguranja. Treba imati u vidu da po pravilu potrošači ne angažuju stručnu pomoć posrednika u osiguranju jer se radi o ugovorima male vrednosti i njihovo angažovanje je za potrošače ekonomski neopravdano. S vremenom se, sa ciljem sticanja i očuvanja poverenja u delatnost osiguranja, nivo zaštite potrošača podiže na sve viši nivo. Direktivom o prodaji osiguranja uvedena je obaveza za prodavce osiguranja da imaju obavezu da pri svakom zaključenju ugovora o osiguranju postupaju pošteno, pravično, profesionalno u najboljem interesu potrošača. ${ }^{35}$

Suženje pojma „potrošač“ na fizičko lice je u skladu sa opredeljenjem u evropskom potrošačkom pravu ${ }^{36} \mathrm{i}$ odlukama Evropskog suda, ${ }^{37} \mathrm{i}$ u tom smislu se definiše pojam „potrošač korisnik usluge osiguranja“. U smislu odredaba kojima se uređuje pružanje usluga osiguranja na daljinu, potrošačem se u francuskom pravu smatra ugovarač osiguranja koji je fizičko lice i koji nastupa u svrhe koje su van njegove trgovačke ili profesionalne delatnosti. ${ }^{38} \mathrm{U}$ nemačkom pravu je primenjen restriktivni pojam potrošača ${ }^{39}$ i usvojena je jedinstvena definicija potrošača u odredbama Građanskog zakonika. ${ }^{40} \mathrm{Na}$ primenu ove definicije potrošača upućuju i odredbe zakona kojim se uređuje ugovor o osiguranju. ${ }^{41}$ Ista definicija se primenjuje i na lice koje zaključuje ugovor o osiguranju ili ostvaruje benefite iz njega, ako ima svojstvo potrošača. ${ }^{42}$ Treba imati u vidu da se zaštita koju nemački zakonodavac pruža povodom ugovora o osiguranju ne ograničava samo na lice koje ima svojstvo potrošača prema odredbama Građanskog zakonika već se proširuje i na lica koja se bave slobod-

34 Ivančević, K., Zaštita potrošača kroz zakonske odredbe koje se odnose na ugovor o osiguranju, u: Slavnić, J., Šulejić, P., Pak, J., (ur.), 2008, „Evropski put“ prava osiguranja Srbije, posebno ugovora o osiguranju, Udruženje za pravo osiguranja Srbije, str. 371.

35 Član 17. Direktive 2016/97; Smernice 2018, str. 4.

36 Ivančević, K., 2010, Pravna zaštita potrošača korisnika usluge osiguranja i bankarske usluge, doktorska disertacija, Pravni fakultet Univerziteta Union, str. 45.

37 Evropski sud je zauzeo stav da se u smislu odredaba Direktive 93/13 potrošačem ne može smatrati pravno lice. Potrošačem se smatra fizičko lice koje zaključuje ugovor koji nije u okviru njegove profesionalne delatnosti. Sud EU, presuda od 22. novembra 2001, povezani predmeti Cape Snc v Idealservice Srl i Idealservice MN RE Sas v OMAI Sri, C-541/99 i C-542/99, EU:C:2001:625.

38 Član 112-2-1. Francuskog ZO.

39 U nemačkom pravu pojam potrošača obuhvata samo fizička lica koja deluju u svrhu koja je van njihove delatnosti, poslovanja ili profesije. Ovaj pristup je prihvaćen u zakonodavstvu, odnosno sudskoj praksi još nekih zemalja (Holandije, Portugalije, Republike Irske, Švedske, Litvanije, Estonije, Finske, Slovenije, Kipra, Rumunije i Bugarske). Ebers, M., Unfair Contract Terms Directive, in: Schulte-Nölke, H. (ed.), 2008, EC Consumer Law Compendium Comparative Analysis, Bielefeld, pp. 376.

40 Jedinstvena definicija potrošača je utvrđena odredbom člana 13. Građanskog zakonika Nemačke (BGB).

41 Odredba Zakona o ugovoru o osiguranju Nemačke, (u daljem tekstu: ZUO Nemačke), upućuje na primenu ove definicije. Gesetz über den Versicherungsvertrag (Versicherungsvertragsgesetz - VVG), par. 214.

42 Keglević, A., 2016, str. 20. 
nim profesijama i kompanijama. ${ }^{43} \mathrm{U}$ engleskom pravu se potrošačem smatra fizičko lice koje zaključuje potrošački ugovor o osiguranju ili predlaže njegovo zaključenje. Ovaj ugovor sa osiguravačem sklapa pojedinac sa svrhom koja u celini ili u pretežnom delu nije vezana za trgovinu, njegovu delatnost ili profesiju. ${ }^{44} \mathrm{U}$ svakom konkretnom slučaju se procenjuje da li neko lice ima svojstvo potrošača imajući u vidu kriterijum svrhe sklapanja ugovora o osiguranju. ${ }^{45}$

U nekim zemljama se pod pojam „potrošač“ svrstavaju ne samo fizička lica već i neka druga lica kada sklapaju ugovor van svoje profesionalne delatnosti. $\mathrm{U}$ grčkom pravu se ugovarač osiguranja i osiguranik smatraju krajnjim korisnicima usluge osiguranja tako da mogu imati status potrošača u smislu zakona kojim se štite potrošači. ${ }^{46}$ Međutim, u smislu zakona kojim se uređuje osiguranje, svojstvo potrošača ima fizičko ili pravno lice, bez obzira na vrstu poslovne aktivnosti kojom se bavi, uz uslov da zaključuje ugovor o osiguranju iz nekomercijalnih razloga. ${ }^{47}$

U uporednom pravu u zakonima novijeg datuma koji uređuju delatnost osiguranja susrećemo se sa definicijom potrošača korisnika usluge osiguranja. Tako se u pravu Federacije BiH pod pojmom „potrošač“, u smislu odredaba zakona kojim se uređuje delatnost osiguranja, podrazumeva „svako fizičko lice koje ima prava i obaveze po ugovoru o osiguranju". 48 Ova definicija nije usklađena sa definicijom pojma „potrošač“ koja je prihvaćena u zakonu kojim se uređuju pravila o zaštiti potrošača. ${ }^{49}$ Svojevremeno je u hrvatskom pravu pojam „potrošač korisnika usluge osiguranja“ bio proširen, što je u teoriji ocenjeno kao „nepotrebno i neopravdano" jer to ne opravdavaju ni priroda izvršenih usluga ni način sklapanja ugovora. ${ }^{50}$ Ova kritika je prihvaćena i u tom smislu je izvršena izmena tako

43 „Cilj zaštite nije samo potrošač nego zaštita 'modernog potrošavstva'“. Samardžić D., 2014, Jačanje položaja potrošača u nemačkom privatnom pravu osiguranja, Anali Pravnog fakulteta u Zenici, 14, str. 181.

44 Consumers Insurance (Disclosure and Representacions) Act (CIDRA), 2012, Zakon o potrošačkom osiguranju, član 1.

45 Keglević, A., 2016, str. 20.

46 U grčkom pravu je primenjena šira definicija potrošača. Potrošačem se smatra svako fizičko ili pravno lice ili udruženje bez pravnog subjektiviteta, kome su namenjeni proizvodi i usluge koje ova lica koriste u svojstvu krajnjeg korisnika. Član 1 (4) Zakona 2251/1994 o zaštiti potrošača. Douga, A. E., 2015, Consumer protection in Greece, especially in insurance contracts, Zbornik radova Pravnog fakulteta u Nišu, 70, godina LIV, str. 841-860. Varijanta proširenja pojma potrošača na pravno lice kada se javlja kao krajnji korisnik prisutna je u zakonodavstvu i sudskoj praksi Austrije, Belgije, Italije, Španije, Grčke, Češke, Slovačke i Mađarske. Ebers, M., 2008, str. 379.

47 Zakon definiše pojam komercijalnih osiguranja kojima se pokrivaju veliki rizici. Law Decree 400/1976. Douga, A. E., 2015, str. 849, 850.

48 Član 197. ZO Federacije BiH.

49 „Potrošač je svako fizičko lice koje kupuje, stiče ili koristi proizvode ili usluge za svoje lične potrebe i za potrebe svoga domaćinstva." Član 1. stav 3. Zakona o zaštiti potrošača u Bosni i Hercegovini, Službeni glasnik BiH, br. 25/06, 88/15.

50 Potrošačem se smatrala svaka fizička osoba koja pribavlja usluge uređene Zakonom o osiguranju. Baretić, M., Zaštita potrošača u Republici Hrvatskoj nakon ulaska u Europsku uniju jesmo li implementacijom europskog prava izgradili sustav zaštite potrošača, u: Bourgoignie, T., Jovanić, T. (ur.), 2013, Strengthening consumer protection in Serbia, Jačanje zaštite potro- 
da je, za potrebe uređenja distribucije osiguranja, definisan pojam „potrošač “ kao fizičke osobe kako je određeno zakonom kojim se uređuje zaštita osnovnih prava potrošača. ${ }^{51}$ To znači da se u hrvatskom pravu potrošačem smatra svaka fizička osoba koja sklapa pravni posao ili deluje na tržištu van svoje trgovačke, poslovne, privredne ili profesionalne delatnosti. ${ }^{52}$ Mišljenja smo da bi ovakvu upućujuću odredbu trebalo ugraditi i u naš ZO.

\section{OCENA PRAVIČNOSTI ODREDABA UGOVORA O OSIGURANJU}

Ugovor po pristupu, u koji se svrstava i ugovor o osiguranju, treba da proizvede određeno pravno dejstvo koje nije protivno važećim propisima, i koje će imati za cilj da zadovolji ne samo interes ugovornih strana nego i da ne povredi opšti interes. ${ }^{53}$ Kod ugovora o osiguranju u odnosima ugovornih strana mora da postoji visok nivo međusobnog poverenja. ${ }^{54}$ Sastavni deo ugovora o osiguranju su opšti i posebni uslovi osiguranja koje sastavljaju osiguravači. Uslovima osiguranja osiguravač ne treba da štiti samo sopstvene interese već i interese osiguranika kako bi se obezbedila svrha zaključenog ugovora o osiguranju. ${ }^{55} \mathrm{Od}$ osiguravača se zahteva da pri sačinjavanju uslova osiguranja postupaju sa pojačanom pažnjom dobrog stručnjaka, uz primenu pravila struke, posebno aktuarske struke, u skladu sa načelom savesnosti i poštenja, sa dobrim poslovnim običajima i poslovnom etikom. ${ }^{56}$ Navedeno podrazumeva da uslovi moraju biti sačinjeni na jasan i razumljiv način i da ne sadrže odredbe koje su nepravične za stranu koja pristupa ugovoru, odnosno koje mogu biti na štetu ugovarača osiguranja. ${ }^{57} \mathrm{Na}$ to ukazuje i očekivanje da osiguravač ne uvodi uslugu osiguranja na tržište ako rezultat testiranja te usluge pokaže da ona nije u skladu sa interesima, ciljevima i karakteristikama ciljnog tržišnog segmenta. ${ }^{58}$ Odredbama uslova koji su sačinje-

šača u Srbiji, Liber Amicorum Svetislav Taboroši, Pravni fakultet Univerziteta u Beogradu, str. 103-104.

51 U tom delu zakona su primenjene odredbe Direktive (EU) 2016/97. Glava XXIII Distribucija osiguranja, član 399. stav 1. tačka 3. Zakona o osiguranju, Narodne novine, br. 30/15, 112/18, $63 / 20$.

52 Član 5. stav 1. tačka 15. ZZP Hrvatske.

53 Blagojević, B., 1934, str. 3.

54 Pavić, D., 2009, Ugovorno pravo osiguranja, Zagreb, TECTUS, str. 60-61.

55 Svrha ugovora se ceni prema subjektivnim elementima uz pomoć kojih se utvrđuje cilj koji se želeo postići konkretnim ugovorom. To nije samo osnovni cilj, kauza, već uključuje i druge okolnosti ugovora koje su bile od značaja za zaključenje baš konkretnog ugovora o osiguranju sa određenim sadržajem. Uključuje zajedničku nameru i očekivanja stranaka koja su vezana za različite elemente ugovora. Član 99. stav 2. ZOO.

56 Ukoliko ne obavljaju delatnost na propisan način, predviđena je sankcija u vidu novčane kazne za društvo i odgovorno lice. Član 260. stav 1. tačka 3) a u vezi sa članom 19. ZO.

57 Pojedini zakoni sadrže posebne odredbe u ovom smislu. Tako na primer: Insurance Contract Act (ICA) No. 2496/97, Greece - Zakon o ugovoru o osiguranju Grčke, (u daljem tekstu: ZUO Grčke), član 2. stav 8; Ley 50/1980, de 8 de octubre, de Contrato de Seguro - Zakon o ugovoru o osiguranju Španije, (u daljem tekstu: ZUO Španije), član 3. stav 1.

58 Ciljni tržišni segment u smislu ove smernice je grupa korisnika za koju osiguravač stvara uslugu osiguranja i kojoj tu uslugu pruža. Smernice, 2018. 
ni u dobroj veri trebalo bi obezbediti ugovornu ravnotežu između osiguravača i slabije ugovorne strane koja pristupa ugovoru, posebno u pogledu prava i obaveza koji su od značaja. ${ }^{59}$ Bitno je da se sačinjavanjem uslova osiguranja jasnim, razumljivim jezikom omogući prosečnom potrošaču da razume obim pokrića i isključenja iz osiguranja koji treba da su precizno definisani bez potrebe za tumačenjem. Ovo je značajno kako se ne bi dešavalo da potrošač otkriva da ove odredbe nije razumeo tek kada osiguravač odbije da plati naknadu iz osiguranja, a što je u praksi čest slučaj. ${ }^{60}$

Praksa pokazuje da se u uslovima osiguranja nalaze odredbe koje su na štetu korisnika usluge osiguranja i da postoji potreba da se obezbedi zaštita od primene ovakvih odredaba. Zaštita od nepravičnih ugovornih odredaba ima za cilj da omogući potrošačima da se njihovi pojedinačni interesi zaštite od ugovornih odredaba koje su primenjene u uslovima osiguranja kao sastavni deo konkretnog ugovora. Značajno za zaštitu potrošača je da oceni pravičnosti mogu biti podvrgnute i odredbe uslova osiguranja po kojima nije zaključen konkretan ugovor. Evropski sud je zauzeo stanovište da činjenica da određena odredba nije primenjena u praksi ne sme biti smetnja za ocenu njene pravičnosti. ${ }^{61}$ Zabranom primene određenih klauzula u uslovima osiguranja, za koje je ocenjeno da su nepravične, postiže se zaštita i za ubuduće, čime se štite i kolektivni interesi potrošača. U pojedinim zemljama, kao na primer u Portugaliji, registruju se i objavljuju odredbe koje su u sudskom sporu oglašene ništavim kako bi se osiguravači i korisnici usluga obavestili o sudskom tumačenju. Portugalski osiguravači imaju u vidu ove odluke prilikom sačinjavanja uslova osiguranja. ${ }^{62}$ Evropski sud je pozitivno ocenio uvođenje nacionalnih registara ugovornih odredaba koje su ocenjene kao nepravične u konačnim sudskim odlukama, smatrajući da se time povećava zaštita potrošača od nepravičnih ugovornih odredaba. ${ }^{63}$ Smatramo da bi ovu dobru praksu trebalo primeniti i kod nas.

U srpskom pravu odredbe ZOO koje uređuju pravila o ništavosti odredaba opštih uslova shodno se primenjuju i na ugovor o osiguranju. Ovim pravilima se određuje da će biti ništave odredbe opštih uslova koje su suprotne cilju zaključenog ugovora ili dobrim poslovnim običajima. Mogućnost primene dobrih poslovnih običaja, odnosno dobrih običaja ZOO predviđa kako bi se korigovala

Osiguravači su u obavezi da uspostave trajan nadzor nad osmišljavanjem proizvoda osiguranja, što podrazumeva i nadzor nad uslovima osiguranja, kao i da proveravaju da li proizvod odgovara ciljnom tržišnom segmentu tokom njegovog plasmana na tržište. Član 25. Direktive $2016 / 97$.

59 Rokas, I. K., Murray, V., 1999, The protection of the consumer under the new greek law 2496/97 on insurance policies, Pravo i privreda, 1-2, str. 73.

60 Kochenburger, P., The language matters: Regulation of insurance policy terms and conditions, u: Marano, P., Jovanović, S., (ur.) 2012, Izazovi usklađivanja prava osiguranja Srbije sa evropskim (EU) pravom osiguranja, Palić, Udruženje za pravo osiguranja Srbije, str. 176.

61 Presuda od 26. januara 2017, Banco Primus, C-421/14, EU:C:2017:60. Presuda od 29 oktobra 2015, BBVA, C-8/14, EU:C:2015:731.

62 Santos, D. M., Portugal, in: Rogan, P. (ed.), 2020, The Insurance and Reinsurance Law Review, eighth edition, Law Business Research Ltd, p. 371.

63 Na osnovu ovog registra, ovlašćena tela su u mogućnosti da kažnjavaju sve trgovce koji koriste iste ili slične odredbe. Uslov je da se trgovcima obezbedi efikasna sudska zaštita po ovim odlukama. Commission notice, pp. 63. 
strogo formalnopravna primena norme u realnim životnim okolnostima. ${ }^{64}$ Sud može odbiti primenu pojedinih odredaba koje lišavaju drugu stranu da stavi prigovore, ili onih na osnovu kojih ona gubi prava iz ugovora ili gubi rokove, ili koje su inače nepravične ili preterano stroge prema njoj. ${ }^{65} \mathrm{Na}$ sudu je odgovorna dužnost da u konkretnoj situaciji primeni odgovarajuća pravila imajući u vidu da je osnovni zadatak da se ne povredi načelo zakonitosti. ${ }^{66}$

Odredbama ZZP-a uvedena su dodatna pravila o nepravičnosti ugovornih odredaba u potrošačkim ugovorima koja se primenjuju i na ugovor o osiguranju. Svaka odredba koja, protivno načelu savesnosti i poštenja ${ }^{67}$ ima za posledicu značajnu nesrazmeru u pravima i obavezama ugovornih strana na štetu potrošača, smatraće se nepravičnom odredbom. Određeni su kriterijumi na osnovu kojih se utvrđuje da li je određena odredba nepravična u pojedinačnim slučajevima, kao i liste nepravičnih ugovornih odredaba. ${ }^{68} \mathrm{U}$ postupku sa zahtevom za ocenu pravičnosti sud mora kao prethodno pitanje da utvrdi da li je konkretna odredba nejasna uz primenu objektivnog kriterijuma, jer postojanje spora ne znači nužno da je odredba nejasna. ${ }^{69}$ Pri proceni pravičnosti odredbe opštih uslova koja je prepoznata kao nejasna primenjuju se posebna pravila o tumačenju u korist slabije ugovorne strane, odnosno potrošača. ${ }^{70} \mathrm{U}$ srpskom pravu se predlaže da se u pogledu ugovora o osiguranju i isprava koje sačinjava osiguravač uvede dodatno pravilo koje predviđa da će se u slučaju sumnje u vezi sa značenjem teksta isprave primeniti tumačenje koje je najpovoljnije za ugovarača, osiguranika ili korisnika osiguranja. ${ }^{71}$

Sva navedena pravila doprinose pojedinačnoj zaštiti potrošača od nepravičnih odredaba ugovora o osiguranju. Posredno, ova pravila utiču na kolektivnu zaštitu potrošača s obzirom na to da osiguravači u skladu sa odlukama sudova koriguju uslove osiguranja bilo samoinicijativno ili po nalogu nadležnog organa. $\mathrm{Na}$ ovakvo ponašanje ih obavezuju i pravila dobre poslovne etike. Očekuje se da osiguravač, ukoliko tokom pružanja usluge osiguranja identifikuje manjkavost određene usluge, sprovede potrebne izmene kako bi umanjio eventualnu nastalu ili buduću štetu za korisnike. ${ }^{72}$

64 Pored dobrih poslovnih običaja ZOO predviđa sa istom svrhom primenu pravičnosti i načela savesnosti i poštenja. Perović, S., 2012, Ugovorna odgovornost i moralna dužnost, Pravna riječ, 32, str. 27.

65 Član 143. ZOO. Na isti način i Prednacrt GZ-a Srbije, član 284.

66 Perović, S., 2012, str. 28.

67 „U zasnivanju obligacionih odnosa i ostvarivanju prava i obaveza iz tih odnosa strane su dužne da se pridržavaju načela savesnosti i poštenja." - član 12. ZOO. U Prednacrtu GZ-a Srbije, ova odredba nalazi se u Opštem delu u Uvodnim odredbama, član 4. Predviđena je izmena u odnosu na odredbu ZOO, tako da ovaj član glasi: „Savesnost i poštenje je vrhovno načelo Zakonika. Primena načela savesnosti i poštenja ne može se isključiti ili ograničiti."

68 Lista odredaba koje se bez obzira na okolnosti pojedinačnog slučaja uvek smatraju nepravičnim i lista odredaba za koje se to pretpostavlja dok se suprotno ne dokaže. Neke od odredaba sa liste su primenjive i na ugovor o osiguranju, ali ne sve. Čl. 43, 44. i 45. ZZP.

69 Vukadinović, S., 2020, Domašaj pravila contra proferentem u tumačenju opštih uslova ugovora, Pravni zapisi, 1, str. 160, 161.

70 Član 100. ZOO; član 42. ZZP. Na isti način i Prednacrt GZ-a Srbije, član 232.

71 Član 1395. stav 2. Prednacrta GZ-a Srbije.

72 Smernice 2018, str. 10. 
U uporednom pravu je takođe uobičajeno da se primenjuju opšta pravila za ocenu pravičnosti odredaba opštih uslova pri proceni odredaba ugovora o osiguranju. Bez dejstva se smatra u litvanskom pravu odredba standardnih opštih uslova iznenađujućeg karaktera, tj. takav uslov koji druga strana nije mogla razumnom pažnjom da očekuje u ugovoru. Međutim, ako je ovaj uslov izričito prihvatila kada je sa njim upoznata, neće se smatrati iznenađujućom klauzulom. ${ }^{73}$ U austrijskom pravu ne postaju sastavni deo ugovora odredbe koje su neuobičajene tako da prema okolnostima konkretnog slučaja osiguranik nije mogao da ih očekuje jer su u neskladu sa tipom ugovora. Sudska praksa je zauzela stav da su odredbe neuobičajene ako osiguranik ne bi trebao da ih prihvati imajući u vidu ocenu konkretnih uslova i "prosečno razumevanje osiguranika." ${ }^{74}$ Treba imati u vidu da neuobičajene klauzule ne moraju biti nepravične, bitno je da potrošač na njih bude upozoren i da razume njihovu sadržinu i svrhu. Neke klauzule koje su uobičajene u uslovima osiguranja mogu biti ocenjene kao nepravične, odnosno sud može odbiti njihovu primenu u konkretnoj situaciji. ${ }^{75}$ Potrošačko pravo se zasniva na principu transparentnosti. U grčkom pravu to podrazumeva preciznost i razumljivost teksta ugovora, određenost sadržaja ugovornih odredaba na način da potrošač može da predvidi svoj pravni položaj kada one budu primenjene i na zabranu neočekivanih, neobjavljenih i prevarnih ugovornih odredaba. ${ }^{76}$ Neočekivanim ili klauzulama iznenađenja se smatraju po oceni sudske prakse one odredbe koje su uticale na formiranje pogrešnog utiska kod potrošača o visini cene ili o predmetu ugovora, odnosno pokriću koje se obezbeđuje. ${ }^{77}$

\subsection{PREDLOG ZA UVOĐENJE POSEBNIH PRAVILA O NEPRAVIČNIM ODREDBAMA UGOVORA O OSIGURANJU U SRPSKO PRAVO}

Predlog je da se u srpskom pravu posebnom odredbom urede pravila o klauzulama zloupotrebe (nepoštene klauzule) ugovora o osiguranju. ${ }^{78}$ Ovaj predlog je dobrim delom usaglašen sa odredbama PEICL-a. ${ }^{79}$ Smatramo da su termini

73 Prilikom određivanja da li uslov ima iznenađujući karakter, u obzir se uzimaju njegova sadržina, tekst i način izražavanja. Član 6.186, st. 1. i 2. Civil code of the Republic of Lithuania 18 July 2000 No VIII-1864 - Građanski zakonik Republike Litvanije, poslednji put izmenjen 12. 4. 2011, No XI-1312, (u daljem tekstu: GZ Litvanije).

74 Ilkić, Z., Pojedina uporedno-pravna shvatanja o klauzulama uslova osiguranja, u: Marano, P., Jovanović, S., Labudović Stanković, J., (ur.), 2013, Pravo osiguranja u tranziciji, Aranđelovac, Udruženje za pravo osiguranja, str. 306.

75 Na primer, uobičajeno je da se u opštim uslovima osiguranja auto kaska unosi odredba da je osiguranik dužan da u slučaju krađe vozila preda osiguravaču originalne ključeve vozila, saobraćajnu dozvolu ukradenog vozila i servisnu knjižicu. U slučaju da osiguranik ne može da preda sva tri, gubi pravo iz osiguranja. U pojedinim situacijama je sud ocenio da su ovakve odredbe uslova osiguranja nepravične i preterano stroge prema osiguraniku.

76 Venieris, I., 2015, „Jednostavni i razumljivi izrazi“ u potrošačkim ugovorima o osiguranju prema grčkoj sudskoj praksi, Evropska revija za pravo osiguranja, 1, str. 20, 21.

77 Venieris, I., 2015, str. 20.

78 Član 1399. Prednacrta GZ-a Srbije.

79 Član 2:304. PEICL. Sastavljači PEICL-a su u ovom delu za uzor imali odredbe Direktive 93/13. 
„nepoštene klauzule“, kao i „klauzule zloupotrebe“ koji se koriste u ovom predlogu neodgovarajući i da ih treba zameniti terminom „nepravične odredbe" koji je prihvaćen i usaglašen u srpskom zakonodavstvu. Naime, formulacija u odredbama ZZP-a je usaglašena sa onom koja se koristi u odredbama ZOO. Termin „nepoštene klauzule" neusaglašen je i sa ostalim odredbama Prednacrta GZ-a Srbije. ${ }^{80}$

Predložena odredba predviđa da ugovarača osiguranja, osiguranika i korisnika osiguranja neće obavezivati klauzula o kojoj se nije posebno pregovaralo a koja stvara značajnu nejednakost u pravima i obavezama po ugovoru na njihovu štetu suprotno principima savesnosti i poštenja. Nejednakost ugovornih strana kod ugovora o osiguranju je prisutna zbog svojstava ugovornika, načina zaključenja, informacione asimetrije, sadržaja ovog ugovora i u tom smislu je osiguravač po pravilu jača ugovorna strana. Druga ugovorna strana ne poseduje specijalizovano znanje tako da se dešava da zaključi ugovor koji ugrožava njena prava i kojim se nekad vređa načelo jednake vrednosti davanja. Da bi bila nepravična, odredba potrošačkog ugovora treba da ima za posledicu značajnu nesrazmeru u pravima i obavezama ugovornih strana na štetu potrošača. ${ }^{81}$ Cilj je da se sankcioniše povreda načela ekvivalentnosti uzajamnih davanja ugovornih strana i da se trgovac (osiguravač) onemogući da postigne korist iz ugovora na štetu slabije ugovorne strane - potrošača (korisnika usluge osiguranja). Formulacija iz ZZP-a koristi se i u odredbama PEICL-a. U tom smislu nam se čini da je formulacija iz ZZP-a adekvatnija od predložene formulacije u ovom predlogu.

Ugovornu odredbu koja je oglašena ništavom treba tretirati kao da nikada nije ni ugovorena i da ne može imati efekta u odnosu prema potrošaču ${ }^{82} \mathrm{Da}$ bi se postigao ovaj efekat, odgovarajuća građanskopravna sankcija je apsolutna ništavost ugovorne odredbe, kako je to uređeno odredbama ZZP-a. ${ }^{83}$ Formu-

80 Član 143. stav 2. ZOO; čl. 41-45. ZZP. U odredbi člana 284, kojom se uređuje ništavost nekih odredaba opštih uslova poslovanja, koristi se termin nepravične odredbe.

81 Član 43. stav 2. ZZP. Navedena formulacija odgovara pravnom standardu „očigledna nesrazmera uzajamnih davanja ugovornih strana", čiji je cilj zaštita interesa slabije ugovorne strane. Da li postoji značajna nesrazmera koja je na štetu potrošača jeste faktičko pitanje o kome odluku donosi sud u svakom konkretnom slučaju. Prilikom procene, nacionalni sud mora da relevantnu ugovornu odredbu uporedi sa pravilima nacionalnog prava koja se primenjuju u slučaju da stranke nisu o tome postigle sporazum. Znatnija neravnoteža se ne može ograničiti na kvantitativno ekonomsko ocenjivanje. Znatnija neravnoteža može da proizilazi iz činjenice da dovoljno ozbiljno oštećuje pravni položaj potrošača bilo u obliku ograničenja sadržaja prava koja ima na osnovu ugovora ili ograničenja u njihovom korišćenju ili u nametanju dodatne obaveze koja nije predviđena nacionalnim pravom. Evropski sud je u više presuda opisao procenu znatnije neravnoteže na navedeni način. Predmet C/415 Aziz, predmet C 226/12 Constructora Principado, predmet C 421/14 Banco Primus; predmet C-186/16 Andriciuc. Commision notice, p. 31.

82 Član 6. stav 1. Direktive 93/13. Ugovorna odredba se smatra neobavezujućom za potrošača i ovaj efekat ne sme da zavisi od toga kada je potrošač osporio njenu valjanost. Commission notice, 4.2 .

83 Član 43. stav 1. ZZP. U teoriji se ističe da se „apsolutna ništavost nepravičnih odredaba u potrošačkim ugovorima može razumeti kao posebna građanskopravna sankcija za povredu načela ekvivalentnosti uzajamnih davanja“. Karanikić Mirić, M., Nepravične odredbe u potrošačkim ugovorima, u: Lilić, S., (ur.), 2009, Pravni kapaciteti Srbije za evropske integracije, knjiga IV, Pravni fakultet Univerziteta u Beogradu, str. 144. 
lacija iz predloga da klauzula ne obavezuje preuzeta ja iz odredbe PEICL-a. Neobaveznost ugovorne odredbe podrazumeva zabranu nastupanja posledica za korisnika usluge osiguranja. Nejasno je da li je predlagač podrazumevao da korisnik usluge osiguranja treba da zahteva pobojnost ove odredbe ili se očekuje da sud po službenoj dužnosti ispita njenu pravičnost. Korisnik usluge osiguranja, kao i potrošač, najčešće se neće pozvati na nepravičnost ovakve klauzule bilo zato što ne poznaje svoja prava ili zato što neće ni pokrenuti spor zbog troškova postupka. Evropski sud je u više slučajeva zaštitu koja se obezbeđuje na osnovu odredaba Direktive 93/13 okarakterisao kao pitanje od javnog interesa. ${ }^{84} \mathrm{U}$ tom smislu smatramo da bi trebalo predvideti kao odgovarajuću sankciju apsolutnu ništavost ovakve odredbe. Ova sankcija bi omogućila ispitivanje pravičnosti klauzule od strane suda po službenoj dužnosti, što bi obezbedilo viši nivo zaštite od nepravičnih odredaba ugovora o osiguranju. Posebno je to važno jer značajan broj kaluzula koje su nepravične isključuju obavezu osiguravača ili ograničavaju prava korisnika usluge osiguranja, a ređe su one koje korisnike obavezuju.

Pri oceni pravičnosti predviđeno je da se uzimaju u obzir vrsta osiguranja, uslovi ugovora i okolnosti u trenutku kada je ugovor zaključen. ${ }^{85} \mathrm{U}$ uporednom pravu se naglašava da je, pored vrste i prirode osiguranja, bitna i svrha zaključenja ugovora kako bi se, u zavisnosti od ranjivosti prosečnog potrošača, za konkretnu vrstu ugovora mogao omogućiti odgovarajući nivo zaštite. ${ }^{86}$ Smatramo opravdanim da se kao kriterijum za ocenu pravičnosti u ovom predlogu predvidi i osnov - cilj zaključenja ugovora. Navedeno bi bilo u saglasnosti sa opštim pravilima o ništavosti odredaba opštih uslova. ${ }^{87}$

Ove odredbe se primenjuju na sve ugovore o osiguranju, što podrazumeva i potrošačke ugovore. Predviđa se više ograničenja primene ovog člana. Primenjivao bi se samo na odredbe o kojima se nije posebno pregovaralo, što podrazumeva klauzule koje su unapred sastavljene od strane osiguravača na čiju sadržinu ugovarač osiguranja nije mogao da utiče, posebno u kontekstu primene opštih uslova formularnog ugovora (standardnih uslova osiguranja). Oceni pravičnosti bi mogle biti podvrgnute odredbe koje ograničavaju ili menjaju pokriće. Međutim, ova odredba se ne bi primenjivala: na adekvatnost sume osiguranja i premije, niti na odredbe koje sadrže bitan opis odobrenog (prihvaćenog) pokrića ili ugovorene premije, pod uslovom da je odredba sačinjena jednostavnim i razumljivim jezikom. ${ }^{88}$ Prema opštim pravilima ugovor-

84 Evropski sud je u više presuda smatrao da je član 6. stav 1. Direktive 93/13 ekvivalentan normama javnog poretka u državama članicama. Commission notice, 1.1; 4.1. pp. 9, 38.

85 Član 1399. stav 1. Prednacrta GZ-a Srbije. Ovaj član je formulisan po ugledu na odredbe člana 2:304, st. 1. i 3. PEICL-a, mada nisu identični.

86 Rokas, I. K., Murray, V., 1999, str. 72.

87 Član 143. stav 1. ZOO, član 284. stav 1. Prednacrta GZ-a Srbije.

88 Član 1399. stav 3. Prednacrta GZ-a Srbije. Zahtev transparentnosti se po oceni Evropskog suda ne može „ograničiti isključivo na razumljivost ugovornih odredaba na formalnoj i jezičkoj osnovi tako da podrazumeva da potrošači moraju biti u stanju da procene ekonomske posledice" ugovorne odredbe ili ugovora. Npr. predmet C 186/16 Andriciuc. Slične izjave 
nog prava, sve odredbe bilo kog ugovora, kao i ugovora o osiguranju, mogu biti podvrgnute oceni pravičnosti. Predloženo rešenje sužava prava korisnika usluge osiguranja, što smatramo da nije prihvatljivo. Nema razloga da korisnici usluge osiguranja budu u nepovoljnijem položaju od korisnika drugih usluga ili kupaca prema odredbama istog zakona. U srpskom pravu je potrošačima odredbama ZZP-a obezbeđen viši nivo zaštite u odnosu na odredbe Direktive 93/13 tako da se ovo ograničenje ocene pravičnosti ne bi primenjivalo na potrošački ugovor o osiguranju. Naime, saglasno odredbama ZZP-a, kod potrošačkih ugovora svaka odredba ugovora o osiguranju može biti podvrgnuta oceni pravičnosti i oglašena nepravičnom. ${ }^{89}$

\section{ZAKONSKA OGRANIČENJA SADRŽAJA UGOVORA O OSIGURANJU}

Osiguravači su u obavezi da prilikom sačinjavanja uslova osiguranja imaju u vidu zakonska ograničenja koja su propisana odredbama kojima se uređuje ugovor o osiguranju, delatnost osiguranja kao i odredbe posebnih zakona kojima se regulišu pojedine vrste osiguranja. Zakonskom zabranom unošenja određenih klauzula u ugovor o osiguranju, odnosno propisivanjem njihove ništavosti ukoliko ih uslovi sadrže, suštinski se vrši kontrola putem pozitivnog zakonodavstva. Na taj način se obezbeđuje da se u ugovorima o osiguranju ne pojavljuju klauzule koje su prepoznate kao nepravične, posebno one kojima se uskraćuju osiguranicima prava koja su im garantovana zakonom.

Princip slobode ugovaranja je značajno ograničen u ugovornom pravu osiguranja. ${ }^{90}$ Najveći broj zakonskih odredaba kojima se uređuje ugovor o osiguranju je imperativne prirode, što je pretežno prihvaćeno i u uporednom pravu. ${ }^{91}$ Prinudnost normi kod ovog ugovora je iskazana na poseban način. ${ }^{92}$ Samo kada je to izričito dopušteno moguće je odstupanje od prinudnih odredaba. Dispozi-

mogu se pronaći npr. u predmetima C 26/13 Kásler i Káslerné Rábai, C 191/15 Verein für Konsumentenforschung protiv Amazon, C 96/14 Van Hove. Commision notice, pp. 26.

89 Član. 43. stav 2. u vezi sa članom 5. stav 1. tačka 21. ZZP. Kontrolu pravičnosti odredbe kojom se određuje predmet ugovora i u slučaju da je transparentna dopušta značajan broj država članica. Karanikić Mirić, M., 2009, str. 144.

90 Učesnici obligacionog odnosa mogu svoj odnos urediti drugačije nego što je odredbama ZOO uređeno, ako iz pojedine odredbe ZOO ili iz njenog smisla ne proizilazi nešto drugo. Član 20. ZOO.

91 U pojedinim zakonima to nije slučaj. U Španiji su odredbe pretežno dispozitivne prirode. Prema Morales, I. G., Casares San Jose-Marti, I., Zakon o ugovoru o osiguranju Španije i predviđene izmene, u: Slavnić, J., Šulejić, P., Pak, J., (ur.), 2008, Evropski put prava osiguranja Srbije, posebno ugovora o osiguranju, Udruženje za pravo osiguranja Srbije i Crne Gore, str. 280-305, str. 296.

92 Moguće je da prinudnost norme bude izrečena u tekstu koji u formulaciji ističe njen prinudni karakter ili da se prinudnost otkriva iz smisla norme. Đurđević, M., Pavić, D., 2016, Nekoliko misli o ograničenjima slobode uređivanja sadržine ugovora u našem savremenom pravu, Pravo i privreda, 7-9, str. 50. 
tivnost je predviđena izuzetno, tako da je manji broj odredaba koje ugovaračima omogućavaju da postupe kako hoće. ${ }^{93}$ Isti način uređenja obaveznosti normi je prihvaćen i u odredbama PEICL-a. ${ }^{94}$

$\mathrm{Na}$ nivou Evropske unije je uočeno da nacionalna pravila ugovornog prava osiguranja koja su imperativne ili poludispozitivne prirode mogu ograničiti prekograničnu ponudu proizvoda osiguranja, iako su ova pravila od značaja za zaštitu potrošača. ${ }^{95}$ Zaštita prava potrošača u ugovorima u osiguranju se smatra zaštitom javnog interesa. Evropski sud pravde je konstatovao još 1986. da je „sektor osiguranja posebno osetljivo područje sa stanovišta zaštite potrošača i to kako korisnika osiguranja tako i osiguranog lica“, tako da „postoje imperativni razlozi koji se odnose na javni interes i koji mogu da opravdaju ograničenje slobode pružanja usluga" u ovoj oblasti. ${ }^{96}$ Pojedini zakonodavci to posebno ističu. ${ }^{97}$

Predloženo je da se u srpsko pravo unese izričita odredba kojom se naglašava da ugovorom ne mogu biti izmenjene prinudne zakonske odredbe koje uređuju ugovor o osiguranju. ${ }^{98}$ Novina je da odstupanje može biti „u korist bilo koje ugovorne strane“ ukoliko je odstupanje od određene odredbe izričito dopušteno, kao i od odredaba koje pružaju ugovornim stranama mogućnost da postupe kako hoće. ${ }^{99} \mathrm{U}$ odredbama PEICL-a je predviđeno da su odstupanja $\mathrm{u}$ korist bilo koje strane dopuštena samo u ugovorima koji pokrivaju velike rizike. ${ }^{100}$ Smatramo da bi predlog u ovom delu trebalo izmeniti i uskladiti sa rešenjem iz PEICL-a.

U uporednom pravu se u zakonu taksativno navodi koje su odredbe apsolutno imperativne u slučaju da se ne ugovara osiguranje od velikih rizika. Jasno razdvajanje pravila u pogledu velikih rizika od ostalih ugovora propisuje portugalsko pravo. U nemačkom pravu je propisano da se ograničenja slobode ugovaranja koja su propisana ne primenjuju na velike rizike i tekuća osiguranja. Definisan je i pojam velikih rizika, kao i u francuskom pravu. ${ }^{101} \mathrm{U}$ srpskom pravu je predloženo da se uvede odredba kojom se ograničenja u pogledu odstupanja od odredaba glave koja uređuje odstupanja od zakonskih normi kojima se uređuje ugovor o osiguranju ne primenjuje na velike rizike. Upućuje se na definiciju

93 Na primer ugovorne strane mogu da ugovore početak dejstva ugovora, rok trajanja ugovora, kao i da se premija plaća prilikom zaključenju ugovora ili da se plaća nakon zaključenja ugovora, na primer u ratama po fakturi osiguravača.

94 Član 1:103. Obavezni karakter, PEICL.

95 Final Report of the Commission Expert Group on European Insurance Contract Law, European Union, 2014, https://www.mpipriv.de/1102853/eicl-finalreport.pdf, p. 26.

96 ECJ $4^{\text {th }}$ December 1986, Case 205/84, Commission v. Germany, no. 30.

97 Zakon određuje da imperativne odredbe o ugovoru o osiguranju kojima se štiti javni interes, posebno potrošači ili treća lica, imaju prvenstvo u primeni na ugovorne odnose bez obzira na merodavno pravo, kao i na to da su se ugovorne strane sporazumele o njegovoj primeni. Član 9. ZR Portugalije.

98 Član 1394. stav 1. Prednacrta GZ-a Srbije.

99 Član 1394. stav 3. Prednacrta GZ-a Srbije.Ovo je izmenjena oderdba člana 900. stav 1. ZOO. Alternativa predviđa da ostane identičan tekst ovog člana ZOO.

100 Član 1:103. stav 3. PEICL.

101 Čl. 12, 13. i dr. ZR Portugalije; par. 210. ZUO Nemačke; član 111-6. Francuskog ZO. 
velikih rizika koja se uređuje pozitivnim propisima, a koja je u srpskom pravu opredeljena u odredbama ZO. ${ }^{102}$

\subsection{ZABRANA OGRANIČENJA ILI SMANJENJA PRAVA POTROŠAČA}

U uporednom pravu se u zakonima kojima se uređuje ugovor o osiguranju propisuje ništavost ili nevažnost pojedinih odredaba ugovora o osiguranju, odnosno uslova osiguranja koji su na štetu ili nisu u korist slabije ugovorne strane, odnosno potrošača. U grčkom pravu ništave su radnje i isprave koje su usmerene na ograničavanje prava ugovarača osiguranja, osiguranika ili korisnika osiguranja, osim ako to nije izričito odobreno odredbama zakona. ${ }^{103} \mathrm{U}$ srpskom pravu iz smisla pojedinih odredaba proizilazi da nije dozvoljeno odstupanje koje nije u korist osiguranika. Analizom sadržaja norme, odnosno zapovesti koju ona sadrži, može biti otkrivena prinudnost, što je u konkretnom slučaju zadatak suda. ${ }^{104}$ Naime, ukoliko nije izričito zakonom ${ }^{105}$ zabranjeno odstupanje od pojedinih odedaba, dopušteno je samo ako je to u nesumnjivom interesu osiguranika. ${ }^{106}$ Odredbama ZOO, za razliku od pojedinih zakona u uporednom pravu, nisu izričito određene odredbe koje se ne mogu menjati na štetu osiguranika što otežava tumačenje u konkretnoj situaciji da li je pravilo relativno imperativno ili ne. ${ }^{107} \mathrm{U}$ ovom pravcu nema predloga za izmene u srpskom pravu. Predložena je izmena koja predviđa da je odstupanje dopušteno „samo ako nije na štetu osiguranika, ugovarača ili korisnika osiguranja“. ${ }^{108}$ Ukoliko se prihvati ova izmena, ubuduće

102 „Odredbe ovog člana ne primenjuju se na osiguranje, saosiguranje i reosiguranje, kao i na zastupanje i posredovanje u osiguranju i reosiguranju rizika koji se po kriterijumima u smislu pozitivnih zakonskih propisa predviđaju kao veliki rizici.“ Alternativa ovom članu predviđa da se zadrži ista formulacija kao u članu 900. ZOO. Član 1394. stav 4. Prednacrta GZ-a Srbije.

Velikim rizicima u smislu ZO smatraju se rizici iz vrste neživotnih osiguranja: osiguranje šinskih vozila, vazduhoplova, plovnih objekata, robe u prevozu, osiguranje od odgovornosti zbog upotrebe vazduhoplova i plovnih objekata. Ako osiguranik obavlja privrednu delatnost, i rizici se odnose na tu delatnost. Velikim rizicima se smatraju osiguranje kredita i osiguranje jemstva. Velikim rizicima se smatraju i osiguranja motornih vozila, imovine od požara i ostala osiguranja imovine, osiguranje od odgovornosti zbog upotrebe motornog vozila, osiguranje od opšte odgovornosti za štetu i osiguranje finansijskih gubitaka, ukoliko osiguranik ispunjava najmanje dva od zakonom propisanih uslova u pogledu bilansne sume, neto prihoda ili prosečnog broja zaposlenih. Član 255. ZO. Ova definicija je usaglašena sa definicijom velikih rizika iz iz člana 13. tačka 27. Direktive 2009/138.

103 Član 33. stav 1. ZUO Grčke.

104 Đurđević, M., Pavić, D., 2016, str. 50.

105 Odredbama ZOO ili nekog drugog zakona. U principu su strane u obligacionim odnosima slobodne da urede svoje odnose po svojoj volji, s tim da to mora biti učinjeno uz poštovanje prinudnih propisa, javnog poretka i dobrih običaja. Član 10. ZOO.

106 Član 900. ZOO. Na primer, dozvoljeno je da rok za isplatu naknade iz osiguranja bude kraći od zakonskog roka od 14 dana.

107 Slavnić, J., 2012, Predlog tema za javnu raspravu o rešenjima koja nisu prihvaćena u Prednacrtu Građanskog zakonika Republike Srbije u odnosu na ugovor o osiguranju, Revija za pravo osiguranja, 2, str. 33.

108 Član 1394. stav 2. Prednacrta GZ-a Srbije. Kao alternativa je predloženo da ostane formulacija iz člana 900. ZOO. 
bi trebalo dokazivati i utvrđivati da li konkretna odredba izaziva ili može izazvati štetne posledice, a ne da li je u nesumnjivom interesu određenih lica. U teoriji je ukazano da je teško da se odredi šta se smatra štetom za osiguranika, kao i da nije prihvatljivo da se vrednuju korist i šteta niti da se međusobno upoređuju. ${ }^{109}$

U nemačkom pravu se zaštita potrošača ispoljava kroz poludispozitivne norme koje se ne mogu menjati protivno zaštićenim pravima potrošača. ${ }^{110}$ Tako se kod ugovora o osiguranju života ne mogu na štetu osiguranika menjati sporazumom odredbe o priznanju ili nepriznanju prava na naknade koje daje osiguravač. Sporazumom se ne mogu menjati na štetu osiguranika ni odredbe zakona koje uređuju osiguranje od odgovornosti, a kojima se uređuje obaveza prijavljivanja osiguravaču činjenica koje mogu imati za posledicu nastanak njegove odgovornosti i dospelosti osiguravačeve obaveze na naknadu iz osiguranja. ${ }^{111}$ Francusko pravo predviđa da se sporazumom može odstupiti od propisanih odredaba koje uređuju ugovor o osiguranju, osim od odredaba kojima se ugovornim stranama ustanovljava neko pravo koje je predviđeno u taksativno navedenim zakonskim odredbama. ${ }^{12} \mathrm{U}$ grčkom pravu je posebna zaštita usmerena ka potrošačima na taj način što se osiguravačima dozvoljava da odstupe od određenih odredaba samo u određenim okolnostima ili u odnosu na poslovne korisnike. ${ }^{113}$

\subsubsection{Izmena visine premije osiguranja}

Kada se ugovara osiguranje sa višegodišnjim trajanjem, uobičajene su klauzule koje daju za pravo osiguravačima da u toku trajanja ugovora menjaju uslove osiguranja ili premiju osiguranja. Jedan od problema u prekograničnom osiguranju predstavlja različit režim kontrole pravičnosti klauzula koje se odnose na promenu premije, uključujući i klauzule o indeksaciji. Posebno se ukazuje da je neophodno da se obezbedi da klauzule o prilagođavanju tarifa budu transparentne za kupce. ${ }^{114} \mathrm{U}$ momentu zaključenja ugovora, potrošač mora biti upoznat sa uslovima za korekciju premije. U grčkoj sudskoj praksi je zauzet stav da je nepravična ugovorna odredba koja daje za pravo osiguravaču da prilikom bilo kog produženja ugovora o osiguranju može da izmeni premiju na osnovu kriterijuma koji nisu navedeni u ugovoru. Ovi kriterijumi treba da su jasni, razlozi za korekciju razumljivi, sa navođenjem okolnosti, uslova i obima korekcije kako

109 Đorđević, S., Samardžić, D., 2014, Nemačko ugovorno pravo osiguranja sa prevodom zakona (VVG), IRZ, Beograd, str. 51.

110 Samardžić, D., 2014, Jačanje položaja potrošača u nemačkom privatnom pravu osiguranja, Anali Pravnog fakulteta u Zenici, 14, str. 181.

111 ZUO Nemačke, čl. 175. u vezi sa čl. 173. i 174; čl. 112, u vezi sa čl. 104. i 106. Zabrana odstupanja na štetu osiguranika je predviđena na više mesta u zakonu: u opštem delu - član 18; za osiguranje od štete - član 87; kod osiguranja pravne zaštite - član 129; kod osiguranja nezgode - član 191; za zdravstveno osiguranje - član 208.

112 Član 111-2. Francuskog ZO.

113 Rokas, I. K., Murray, V., 1999, str. 72.

114 Final Report of the Commission Expert Group on European Insurance Contract Law, European Union, 2014, p. 78. 
bi se mogao proveriti obračun, uz navođenje trenutka kada se vrši korekcija, kao i načina obaveštavanja potrošača o korekciji. Korekcija ne sme da ima za cilj ostvarivanje dobiti za osiguravača jer se time remeti ugovorna ravnoteža na štetu potrošača. ${ }^{115}$ Klauzule koje dozvoljavaju osiguravaču da poveća premiju iako nije došlo do povećanja rizika nisu prihvatljive s obzirom na to da mogu biti na štetu potrošača. ${ }^{116}$ Ništave su odredbe kojima češki osiguravač daje sebi za pravo da izmeni visinu premije osiguranja iz razloga koji se ne odnose na promenu elemenata na osnovu kojih se utvrđuje premija, kao i odredba kojom u osiguranju lica daje sebi pravo da izmeni visinu premije zbog godina ili zdravstvenog stanja osiguranika. ${ }^{117}$

Kod višegodišnjih ugovora o osiguranju od presudne je važnosti za osiguravače da imaju mogućnost prilagođavanja visine premije osiguranja. Međutim, kroz sudsku praksu su klauzule o promeni premije osiguranja u skladu sa odredbom člana 143. ZOO oglašavane nepravičnim, nekada preterano strogim za osiguranike i kao takve podložne ništavosti. ${ }^{118} \mathrm{Sa}$ ciljem da se zakonska norma usaglasi sa praksom, predloženo je da se u srpskom pravu novom odredbom uredi ovo pitanje. ${ }^{19}$ Odredba uvodi obavezu za osiguravača da obavesti ugovarača osiguranja o izmeni premijskog sistema (tarife) najkasnije mesec dana pre isteka tekućeg jednogodišnjeg perioda osiguranja. Ugovarač osiguranja ima rok od trideset dana da otkaže ugovor i ukoliko to ne učini, novi premijski sistem će se primeniti na početku narednog perioda osiguranja. ${ }^{120}$ Nije predviđena sankcija za propuštanje obaveze obaveštavanja ugovarača osiguranja o promeni tarife, što smatramo da je propust. U predlogu nedostaju odredbe o kriterijumima koji mogu biti osnov za izmenu visine premije, kao i o obavezi da ugovarač osiguranja, posebno potrošač, mora biti sa ovom mogućnosti upoznat u momentu zaključenja ugovora.

\subsubsection{Odredbe o odustanku od ugovora}

U literaturi je pozitivno ocenjeno pravo potošača na odustanak od ugovora o osiguranju. ${ }^{121} \mathrm{U}$ evropskom pravu je propisano da države članice treba da propišu da se od ugovora o životnom osiguranju može odustati u roku od 14 do

115 Venieris, I., 2015, str. 23.

116 Evropska komisija je donela Pravilnik br. 358/2003 o primeni člana 81. stav 3. Amsterdamskog sporazuma kod određene kategorije ugovora, odluka i uobičajene prakse u delatnosti osiguranja. OJ CE No L 53/8 iz 2003. (u daljem tekstu: Pravilnik, 2003). Ivančević, K., 2008, str. 385.

117 Član 2785. Act No. 89/2012 Coll. the Civil Code - Građanski zakonik Češke Republike, (u daljem tekstu: GZ Češke).

118 Šulejić, P., Ugovor o osiguranju u prednacrtu Građanskog zakonika Srbije od 2010. godine, u: Slavnić, J., Jovanović, S., (ur.) 2010, Evropske (EU) reforme u pravu osiguranja Srbije, Udruženje za pravo osiguranja, Intermeks, str. 171.

119 Šulejić, P, 2010, str. 171.

120 Obaveštenje mora biti učinjeno pismeno ili na drugi podoban način na koji ugovarač osiguranja sigurno može dobiti obaveštenje. Isti postupak je predviđen i za slučaj promene opštih uslova osiguranja. Član 1412. Prednacrta GZ-a Srbije.

121 Lemor, U., 2004, Consumer protection in the European single market, CEA policy report, p. 10. 
30 dana, kao i da je osiguravač u obavezi da pre zaključenja ugovora osiguraniku dostavi informaciju o načinu i postupku za odustanak od ugovora. ${ }^{122}$ Kreatori PEICL-a su predvideli pravo na odustanak od ugovora u roku od dve nedelje kod svih ugovora o osiguranju, odnosno u roku od mesec dana kod ugovora o osiguranju života. ${ }^{123}$

Ovo pravo je u svim zemljama priznato potrošačima kod ugovora koji su zaključeni na daljinu, kao i u srpskom pravu. ${ }^{124} \mathrm{U}$ pojedinim zemljama ${ }^{125}$ je ovo pravo priznato nezavisno od toga kojom tehnikom je ugovor zaključen. U estonskom pravu je predviđeno pravo ugovarača osiguranja da odustane od ugovora o osiguranju koji je zaključen na period duži od godinu dana u roku od 14 dana od dana zaključenja ugovora nezavisno od tehnike zaključenja ugovora. Odredbe kojima se otežava ostvarenje prava na odustanak od ugovora ugovarača osiguranja koji je potrošač su ništave, posebno ako se odustanak uslovljava plaćanjem većeg iznosa novca ili ugovorene kazne. ${ }^{126} \mathrm{U}$ francuskom pravu pravo na odustanak od ugovora u roku od 14 dana ima fizičko lice kome se nudi usluga u njegovoj kući, mestu stanovanja ili na radnom mestu. Pod pretnjom ništavosti ugovora ponuda za osiguranje, odnosno ugovor mora da sarži model pisma za ostvarivanje prava za odustanak od ugovora. ${ }^{127} \mathrm{U}$ srpskom pravu je propisano da je ništava odredba ugovora na daljinu ili izjava volje kojom se korisnik odriče prava koja su mu utvrđena zakonom. ${ }^{128}$

U Prednacrtu GZ-a Srbije predlaže se da pravo na odustanak od ugovora ima ugovarač osiguranja koji je fizičko lice koje deluje van okvira svoje komercijalne ili profesionalne delatnosti. Ovo lice bi imalo pravo na odustanak od ugovora u roku od 14 dana, odnosno 30 dana kod osiguranja života, kod ugovora zaključenog između odsutnih strana. ${ }^{129}$ Ovo pravo bi trebalo priznati kod svih ugovora o osiguranju, a ne samo u slučaju ugovora zaključenih između odsutnih lica uz određena ograničenja, ${ }^{130}$ kao i predvideti sankciju ništavosti odredaba kojima se otežava ili onemogućava ostvarenje ovog prava.

122 Član 186. stav 1. i član 183. Direktive 2009/138/EU.

123 Čl. 2:203 i 17:203 PEICL. Navedeno je kada se ovo pravo ne može koristiti.

124 Direktiva 2002/65/EC koja je primenjena u državama članicama i u srpskom pravu. Čl. 1317. ZZKFUD.

125 U grčkom pravu je rok za odustanak 14 dana od dana uručenja polise kod ugovora o neživotnom osiguranju sa pokrićem dužim od godinu dana i kod osiguranja lica - član 8 . stav 3 . ZUO Grčke. U nemačkom pravu je za sve ugovore o osiguranju rok za odustanak 14 dana od dana prijema polise i opštih uslova, odnosno dobijanja informacije o pravu na odustanak. Ovo pravo ne postoji kod ugovora koji su zaključeni na rok kraći od mesec dana, kod osiguranja velikih rizika, kao i kada nije zaključen ugovor na daljinu kod osiguranja privremene zaštite i penzijskog osiguranja - član 8. ZUO Nemačke. Član 433. stav 1. tačka 5. ZOO Estonije.

127 Ovaj član se ne primenjuje na ugovore o osiguranju života, na osiguranje putovanja ili prtljaga ili na ugovore o osiguranju sa trajanjem do mesec dana - član 112-9. Francuskog ZO. Član 23. ZZKFUD.

129 Član 1414. stav 1. Prednacrta GZ-a Srbije.

130 Ivančević, K., 2008, str. 381. Ograničenja bi se odnosila na ugovore zaključene na period kraći od mesec dana i ugovore kojima se pruža privremena zaštita. 


\section{UMESTO ZAKLJUČKA}

Nesumnjivo je da su rešenja iz Prednacrta GZ-a Srbije u pogledu ugovora o osiguranju predvidela značajne izmene koje doprinose boljoj uređenosti ovog ugovora. Rešenja iz ZOO su bila dobra, ali je postojala potreba da se određene praznine koje su se pokazale u primeni nadomeste zakonskim rešenjima. Solidan nivo zaštite koji imaju korisnici usluge osiguranja kroz odredbe ZOO se može podići na znatno viši nivo, posebno zaštita potrošača. U ovom radu smo razmotrili pojedine novine iz Prednacrta GZ-a Srbije i ukazali na određena uporednopravna rešenja koja nam se čine kao dobri primeri.

$\mathrm{U}$ uporednom pravu se prepoznaje tendencija zakonodavaca da formiraju „liste“ tzv. crnih klauzula propisivanjem ništavosti pojedinih odredaba ugovora o osiguranju koje su u praksi prepoznate i okarakterisane kao nepravične. Ovo se ne čini popisom ovih klauzula na jednom mestu, već izričitim propisivanjem ništavosti određenih klauzula prilikom uređenja pojedinih vrsta osiguranja. Srpski zakonodavac nije prihvatio ovaj metod, ali bi o njemu trebalo razmisliti s obzirom na to da postoji praktična potreba za takvim načinom zaštite. Pri kreiranju određenih rešenja u Prednacrtu GZ-a Srbije korišćena su iskustva iz uporednog prava, savremene tendencije koje su izražene u evropskom pravu, kao i iskustva domaće prakse osiguranja i sudske prakse. Predlozi za izmene predloženih rešenja koje smo izneli u ovom članku dati su sa namerom da se doprinese pronalaženju najadekvatnijih formulacija i poboljšanja datih predloga.

Postoji i tendencija savremenih zakonodavaca da se pri uređenju pravila o ugovoru o osiguranju detaljnije uređuju pojedine vrste osiguranja. U Prednacrtu GZ-a Srbije preuzeta je tradicionalna podela iz ZOO i uređenje osnovnih vrsta osiguranja. Postoji potreba za sveobuhvatnijom reformom ugovora o osiguranju. Navedeno podrazumeva detaljnije uređenje pojedinih vrsta osiguranja. Pozdravljamo detaljnije uređenje osiguranja od odgovornosti. Nedostaju odredbe o osiguranju pravne zaštite koje se danas izdvaja kao značajno samostalno osiguranje. Smatramo da navedeno predstavlja jak argument za podršku incijativi da se uređenje ugovora o osiguranju sprovede donošenjem posebnog zakona o ugovoru o osiguranju. U mnogim zemljama se ugovor o osiguranju uređuje posebnim zakonom. Izdvajanje ugovora o osiguranju iz Građanskog zakonika Srbije i donošenje Zakona o ugovoru o osiguranju inicirano je u brojnim referatima koji su izlagani na tradicionalnim godišnjim savetovanjima koje je organizovalo Udruženje za pravo osiguranja, što je konstatovano i u Porukama sa ovih skupova počev od 2004. godine nadalje. ${ }^{131}$

131 Ista inicijativa je ponovljena i u radovima objavljenim u Reviji za pravo osiguranja, kasnije Evropskoj reviji za pravo osiguranja. Komisiji za izradu GZ-a Srbije su upućeni brojni obrazloženi predlozi autora koji su učestvovali na skupovima Udruženja. Podaci o porukama sa Savetovanja su dostupni na internet stranici Udruženja za pravo osiguranja http://www. srbija-aida.org/ kao i radovi na stranici Evropske revije za pravo osiguranja http://www. erevija.org/. 


\section{LITERATURA}

1. Blagojević, B., 1934, Ugovori po pristupu (formularni ugovori), doktorska disertacija, Beograd.

2. Baretić, M., Zaštita potrošača u Republici Hrvatskoj nakon ulaska u Europsku uniju - jesmo li implementacijom europskog prava izgradili sustav zaštite potrošača, u: Bourgoignie, T., Jovanić, T. (ur.) 2013, Strengthening consumer protection in Serbia, Jačanje zaštite potrošača u Srbiji, Liber Amicorum Svetislav Taboroši, Pravni fakultet Univerziteta u Beogradu.

3. Douga, A. E., 2015, Consumer protection in Greece, especially in insurance contracts, Zbornik radova Pravnog fakulteta u Nišu, broj 70, godina LIV.

4. Đorđević, S., Samardžić, D., 2014, Nemačko ugovorno pravo osiguranja sa prevodom zakona (VVG), Beograd, IRZ.

5. Đurđević, M., Pavić, D., 2016, Nekoliko misli o ograničenjima slobode uređivanja sadržine ugovora u našem savremenom pravu, Pravo i privreda, 7-9.

6. Ebers, M., 2008, Unfair Contract Terms Directive, in: Schulte-Nölke, H., (ed.), EC Consumer Law Compendium - Comparative Analysis, Bielefeld.

7. Ilkić, Z., Pojedina uporedno-pravna shvatanja o klauzulama uslova osiguranja, u: Marano, P., Jovanović, S., Labudović Stanković, J., (ur.) 2013, Pravo osiguranja u tranziciji, Aranđelovac, Udruženje za pravo osiguranja.

8. Ivančević, K., Usklađenost regulative Republike Srbije sa evropskim pravom u domenu zaštite potrošača usluge osiguranja, u: Slavnić, J., Pak, J., (ur.) 2011, Promene u pravu osiguranja Srbije u okviru evropskog (EU) razvoja prava osiguranja, Udruženje za pravo osiguranja Srbije.

9. Ivančević, K. 2010, Pravna zaštita potrošača korisnika usluge osiguranja i bankarske usluge, doktorska disertacija, Pravni fakultet Univerziteta Union.

10. Ivančević, K. Zaštita potrošača kroz zakonske odredbe koje se odnose na ugovor o osiguranju, u: Slavnić, J., Šulejić, P., Pak, J., (ur.) 2008, „Evropski put“ prava osiguranja Srbije, posebno ugovora o osiguranju, Udruženje za pravo osiguranja Srbije.

11. Karanikić Mirić, M., Nepravične odredbe u potrošačkim ugovorima, u: Lilić, S., (ur.). 2009, Pravni kapaciteti Srbije za evropske integracije, knjiga IV, Pravni fakultet Univerziteta u Beogradu.

12. Keglević, A., 2016. Ugovorno pravo osiguranja, Zagreb, Školska knjiga.

13. Keglević, A., 2013, Zaštita osiguranika pojedinca kod ugovora o osiguranju, Zbornik Pravnog fakulteta Sveučilišta u Rijeci, Vol. 34, br. 1.

14. Kochenburger, P., The language matters: Regulation of insurance policy terms and conditions, u: Marano, P., Jovanović, S., (ur.) 2012, Izazovi usklađivanja prava osiguranja Srbije sa evropskim (EU) pravom osiguranja, Palić, Udruženje za pravo osiguranja Srbije.

15. Lemor, U., 2004, Consumer protection in the European single market, CEA policy report.

16. Morales, I. G., Casares San Jose-Marti, I., Zakon o ugovoru o osiguranju Španije i predviđene izmene, u: Slavnić, J., Šulejić, P., Pak, J., (ur.) 2008., Evropski put prava osiguranja Srbije, posebno ugovora o osiguranju, Udruženje za pravo osiguranja Srbije i Crne Gore.

17. Pavić, D., 2009, Ugovorno pravo osiguranja, Zagreb, TECTUS.

18. Perović, S., 2012, Ugovorna odgovornost i moralna dužnost, Pravna riječ, 32. 
19. Rokas, I. K., Murray, V., 1999, The protection of the consumer under the new Greek law 2496/97 on insurance policies, Pravo i privreda, 1-2.

20. Samardžić, D., 2014, Jačanje položaja potrošača u nemačkom privatnom pravu osiguranja, Anali Pravnog fakulteta u Zenici, 14.

21. Santos, D. M., Portugal, in: Rogan, P., (ed.) 2020, The Insurance and Reinsurance Law Review, eighth edition, Law Business Research Ltd..

22. Slavnić, J., 2012, Predlog tema za javnu raspravu o rešenjima koja nisu prihvaćena u Prednacrtu Građanskog zakonika Republike Srbije u odnosu na ugovor o osiguranju, Revija za pravo osiguranja, 2.

23. Šulejić, P., 2010, Predlog tema za javnu raspravu o novim rešenjima koja sadrži Prednacrt Građanskog zakonika RS u odnosu na ugovore o osiguranju, Pravni život, 11.

24. Šulejić, P., Ugovor o osiguranju u prednacrtu Građanskog zakonika Srbije od 2010. godine, u: Slavnić, J., Jovanović, S., (ur.) 2010, Evropske (EU) reforme u pravu osiguranja Srbije, Udruženje za pravo osiguranja, Intermeks.

25. Venieris, I., 2015, „Jednostavni i razumljivi izrazi“ u potrošačkim ugovorima o osiguranju prema grčkoj sudskoj praksi, Evropska revija za pravo osiguranja, 1.

26. Vukadinović, S., 2020, Domašaj pravila contra proferentem u tumačenju opštih uslova ugovora, Pravni zapisi, 1.

\section{PROPISI}

1. Act No. 89/2012 Coll. the Civil Code - Građanski zakonik Češke Republike, (http:// www.psp.cz/sqw/sbirka.sqw? $\mathrm{r}=2012 \& \mathrm{cz}=89$ ).

2. Consumers Insurance (Disclosure and Representacions) Act (CIDRA), 2012. - Zakon o potrošačkom osiguranju, (https://www.legislation.gov.uk/ukpga/2012/6/contents/enacted).

3. Decreto-Lei n. ${ }^{\circ} 72 / 2008$, Diário da República, $1 .^{a}$ série $-N .^{\circ} 75-16$ de Abril de 2008, With the amendments implemented by Law no. 147/2015. Zakon Republike Portugalije, (https://dre.pt/application/dir/pdf1sdip/2008/04/07500/0222802261.pdf).

4. Civil code Hungary, Chapter XLV, Insurance - Građanski zakonik Mađarske, (http:// www.aida.org.uk/pdf/Civil\%20Code\%20Insurance\%20-\%20Hungary.pdf).

5. Civil code of the Republic of Lithuania 18 July 2000 No VIII-1864 - Građanski zakonik Republike Litvanije, poslednji put izmenjen 12. 4. 2011, No XI-1312.

6. Gesetz über den Versicherungsvertrag (Versicherungsvertragsgesetz - VVG) - Zakon o ugovorima o osiguranju Republike Nemačke, (http://www.aida.org.uk/AIDAEurop/Germany.asp).

7. Insurance Contract Act (ICA) No. 2496/97, Greece, Službeni list Republike Grčke, tom I, br. 87, 16. 5. 1997, Zakon o ugovoru o osiguranju Grčke, (http://www.aida.org. uk/pdf/Greek\%20Insurance\%20Act.pdf).

8. Law of Obligations Act / Võlaõigusseaduses/ Law of Obligations Act ESTONIA /, Zakon o obligacionim odnosima Estonije, (https://www.riigiteataja.ee/en/eli/506112013011/ consolide).

9. Ley 50/1980, de 8 de octubre, de Contrato de Seguro - Zakon o ugovoru o osiguranju Španije, (http://www.dgsfp.mineco.es/sector/documentos/legislacion/2013/ LEY\%2050.1980,\%20DE\%208\%20DE\%20OCTUBRE,\%20DE\%20CONTRATO\%20 DE\%20SEGURO.pdf). 
10. Loi du 27 juillet 1997 sur le contrat d'assurance - Zakon o ugovoru o osiguranju Luksemburga od 24 jula 1997. godine, (http://www.caa.lu/uploads/documents/files/ Loi_ContratAssurance_1997-07-27_coord_2020-01-01.pdf).

11. French Insurance Code - Zakonik o osiguranju Francuske, (http://aida.org.uk/pdf/ French\%20Insurance\%20Code\%202004.pdf).

12. Narodna banka Srbije, Smernice o minimalnim standardima ponašanja i dobroj poslovnoj praksi učesnika na tržištu osiguranja, od 2. aprila 2018. G. br. 3092

13. Prednacrt Građanskog zakonika Republike Srbije, (Prednacrt GZ-a Srbije), Pravni život, 5-6/2016/Godina LXV/ Knjiga 581.

14. Republic of Bulgaria, Insurance code, December 8, 2005, Zakonik o osiguranju Bugarske, (http://www.aida.org.uk/pdf/Bulgarian\%20Insurance\%20Code\%202005.pdf).

15. Restatement of European Insurance Contract Law, Principles of European Insurance Contract Law, (PEICL) 1. novembar 2015, (www.restatement.info).

16. The Law of 4 April 2014 "on insurance", The Belgian State Gazette (Moniteur Belge) of 30 April 2014, Zakon o osiguranju Kraljevine Belgije.

17. Zakon o obligacionim odnosima (ZOO), Sl. list SFRJ, br. 29/78, 39/85, 45/89 i 57/89, Sl. list SRJ, br. 31/93, Sl. list SCG, br. 1/03 - Ustavna povelja (ZOO).

18. Zakon o osiguranju, Sl. glasnik RS, br. 139/14.

19. Zakon o obaveznom osiguranju u saobraćaju, Sl. glasnik RS, br. 51/09, 78/11, 101/11, 93/12, 7/13 - odluka US.

20. Zakon o zaštiti potrošača, Sl. glasnik RS, br. 62/14 i 6/16 (dr. zakon).

21. Zakon o zaštiti korisnika finansijskih usluga kod ugovora na daljinu, Sl. glasnik $R S$, br. $44 / 18$.

22. Zakon o osiguranju, Sl. novine Federacije BiH, br. 23/17.

23. Zakon o zaštiti potrošača u Bosni i Hercegovini, Sl. glasnik BiH, br. 25/06, 88/15.

24. Zakon o zaštiti potrošača, Narodne novine, br. 41/14, 110/15, 14/2019.

25. Zakon o osiguranju, Narodne novine, br. 30/15, 112/18, 63/20.

26. Uredba o dobrovoljnom zdravstvenom osiguranju, Sl. glasnik RS, br. 108/08, 49/09.

\section{DOKUMENTI EU}

1. Commission notice - Guidance on the interpretation and application of Council Directive 93/13/EEC on unfair terms in consumer contracts (Text with EEA relevance.) OJ C 323, 27. 9. 2019.

2. Council Directive 93/13/EEC of 5 April 1993 on unfair terms in consumer contracts, Official Journal L 95, 21. 4. 1993.

3. Directive (EU) $2016 / 97$ of the European Parliament and of the Council of 20 January 2016 on insurance distribution.

4. Directive 2009/138/EC of the European Parliament and of the Council of 25 November 2009 on the taking up and pursuit of the business of Insurance and Reinsurance (Solvency II), OJ L 335, 17/12/2009, p. 0001-0155.

5. Directive 2002/65/EC of the European Parliament and of the Council of 23 September 2002 concerning the distance marketing of consumer financial services and amending Council Directive 90/619/EEC and Directives 97/7/EC and 98/27/EC, OJ L 271, 9. 10. 2002. 
6. Directive 2011/83/EU of the European Parliament and of the Council of 25 October 2011 on consumer rights, amending Council Directive 93/13/EEC and Directive 1999/44/EC of the European Parliament and of the Council and repealing Council Directive 85/577/EEC and Directive 97/7/EC of the European Parliament and of the Council Text with EEA relevance, 22. 11. 2011, OJ EU L 304/64.

7. Final Report of the Commission Expert Group on European Insurance Contract Law, European Union, 2014, https://www.mpipriv.de/1102853/eicl-finalreport.pdf.

8. Fitness Check of Consmuer and Marketing Law, Brussels, 23. 5. 2017. SWD (2017) 208 final.

9. Pravilnik br. 358/2003 o primeni člana 81. stav 3. Amsterdamskog sporazuma kod određene kategorije ugovora, odluka i uobičajene prakse u delatnosti osiguranja, $O J$ CE No L 53/8 iz 2003.

\title{
CONSUMER PROTECTION OF INSURANCE SERVICES USER AGAINST UNFAIR CONTRACT TERMS
}

\author{
Katarina Ivančević
}

\section{SUMMARY}

The subject of this paper is to consider how to protect the interests of insurance services users who have the status of consumers in Serbian and comparative law through the provisions of the law governing the insurance contract. The paper discusses the legislative solutions of Serbian law and comparative law, the provisions of PEICL, as well as the changes proposed in Serbian law in the Preliminary Draft of the Civil Code of the Republic of Serbia. The analysis showed that there is a need to define the concept of insurance services users in Serbian law and practice. It is pointed out that the provisions of the Law on Insurance lack a reference to the application of the Law on Consumer Protection, as well as in the Preliminary Draft of the Civil Code of Serbia. The solutions from the Preliminary Draft of the Civil Code of Serbia are largely in line with modern solutions from comparative law and the provisions of PEICL. The proposal from the Preliminary Draft of the Civil Code of Serbia to modernize the current provisions governing the insurance contract in Serbian law by introducing special rules governing issues of importance for unfair clauses is positive. The conclusion is that the provisions governing the insurance contract could be improved and supplemented with new provisions in order to ensure a higher level of protection of insurance services users, especially consumers, from unfair contractual provisions. Some comparative legal solutions presented in this paper can serve as a good example. The author gives her suggestions and proposals for changing the proposed solutions.

Key words: insurance services user, unfair contractual provisions, protection of consumers. 